\title{
Process simulation and techno-economic assessment of SER steam gasification for hydrogen production
}

\author{
Daniel Schweitzer ${ }^{a, *}$, Friedemann Georg Albrecht ${ }^{b, * *}$, Max Schmid ${ }^{a}$, \\ Marcel Beirow ${ }^{a}$, Reinhold Spörl ${ }^{a}$, Ralph-Uwe Dietrich ${ }^{b}$, Antje Seitz ${ }^{b}$ \\ a IFK (Institute of Combustion and Power Plant Technology), University of Stuttgart, Pfaffenwaldring 23, 70569 \\ Stuttgart, Germany \\ b TT (Institut für Technische Thermodynamik), Deutsches Zentrum für Luft- und Raumfahrt e.V. (DLR), \\ Pfaffenwaldring 38-40, 70569 Stuttgart, Germany
}

\section{A R T I C L E I N F O}

\section{Article history:}

Received 4 May 2017

Received in revised form

29 October 2017

Accepted 1 November 2017

Available online $\mathrm{xxx}$

Keywords:

SER gasification

Steam gasification

Pilot scale demonstration

Hydrogen production

Techno-economic assessment

Hydrogen production costs

\begin{abstract}
A B S T R A C T
In the SER (sorption enhanced reforming) gasification process a nitrogen-free, high calorific product gas can be produced. In addition, due to low gasification temperatures of 600 $-750^{\circ} \mathrm{C}$ and the use of limestone as bed material, in-situ $\mathrm{CO}_{2}$ capture is possible, leading to a hydrogen-rich and carbon-lean product gas. In this paper, results from a bubbling fluidised bed gasification model are compared to results of process demonstration tests in a $200 \mathrm{~kW}_{\text {th }}$ pilot plant.

Based upon that, a concept for the hydrogen production via biomass SER gasification is studied in terms of efficiency and feasibility. Capital and operational expenditures as well as hydrogen production costs are calculated in a techno-economic assessment study. Furthermore, market framework conditions are discussed under which an economic hydrogen production via SER gasification is possible.
\end{abstract}

๑ 2017 Hydrogen Energy Publications LLC. Published by Elsevier Ltd. All rights reserved.

\section{Introduction}

Ambitious targets for reducing the release of greenhouse gases, as defined in different global emission treaties such as the Kyoto Protocol and the Paris Agreement [1,2], require an extensive reduction of greenhouse gas (GHG) emissions globally. While the share of $\mathrm{CO}_{2}$ free electrical energy (by increasing the share or renewable energy or by introducing CCS \& CCU technologies) is increasing, the share of renewable energy in other energy intensive applications such as transport, heating or chemical industry is still low [3].

A hydrogen based economy could be a way for reducing the $\mathrm{CO}_{2}$ emissions from sectors other than power production since hydrogen can be used as a transport fuel (e.g. in fuel cells) and as a raw product for the chemical industry.

\footnotetext{
* Corresponding author.

** Corresponding author.

E-mail addresses: Daniel.Schweitzer@ifk.uni-stuttgart.de (D. Schweitzer), Friedemann.Albrecht@dlr.de (F.G. Albrecht). https://doi.org/10.1016/j.ijhydene.2017.11.001 0360-3199/@ 2017 Hydrogen Energy Publications LLC. Published by Elsevier Ltd. All rights reserved.
} 